\title{
Erratum to: Changes in attention to an irrelevant cue that accompanies a negative patterning discrimination
}

\author{
Jemma C. Dopson • Guillem R. Esber • John M. Pearce
}

Published online: 10 January 2012

(C) Psychonomic Society, Inc. 2012

\section{Erratum to: Learn Behav}

DOI: $10.3758 / \mathbf{s} 13420-011-0029-3$

The title of the original publication contains an error. The phrase "negative attending discrimination" should read "negative patterning discrimination." The publisher regrets the error.

The online version of the original article can be found at http://dx.doi. org/10.3758/s13420-011-0029-3.

J. C. Dopson $(\bowtie) \cdot$ J. M. Pearce

School of Psychology, Cardiff University,

Cardiff CF10 3AT, Wales

e-mail: dopsonj@cf.ac.uk

J. M. Pearce

e-mail: pearcejm@cardiff.ac.uk

G. R. Esber

Department of Anatomy and Neurobiology,

University of Maryland School of Medicine,

Baltimore, MD, USA 